\title{
The Dynamics of Confederalism and Federalism: Comparing Switzerland and the $\mathbf{E U}$
}

\author{
CLIVE CHURCH AND PAOLO DARDANELLI \\ Centre for Swiss Politics, Department of Politics and IR, University of Kent
}

\begin{abstract}
This article outlines the modern historical evolution of the Swiss political system and describes the main features of its contemporary federalism. In particular, it focuses on how the division of competences and the distribution of power have changed over time, on the factors which have driven these changes, leading to a description of the current situation created by these developments. It then compares the Swiss experience with that of the European Union and draws some lessons from this for the debate on the evolution of the European Union and, in particular, on the adoption and the ratification of the Constitutional Treaty. Although it emphasizes the role of historical experiences and of political culture in shaping Swiss federalism and the difficulties, if not the impossibility, of replicating them in the European context, it concludes that the EU could learn from Switzerland but may not do so.
\end{abstract}

Key Words: EU, Switzerland, federalism, confederalism, Constitutional Treaty

\section{Introduction}

Switzerland as a federal state is a relatively recent creation, dating only from 1848, but it has a long confederal history stretching back to the fourteenth century and even, if one believes the official rhetoric, to $1291 .^{1}$ It is thus seen as the country which more than any other embodies the spirit of the federal idea. Naturally, all those interested in the federal idea and how it can be put into practice look to Switzerland in search of inspiration. This is even more true in the case of those regarding Switzerland as an example of a successful federal state rooted in a pluri-cultural, if not pluri-national, society. Students and observers of the process of European integration and especially of its 'end-state' - often debated in relation to the federal model - figure prominently among the latter. ${ }^{2}$ In this article, we follow this tradition, describing the historical evolution and the present reality of Swiss federalism and presenting an interpretation of the 
forces that have shaped it over time and which sustain it today, with a view to drawing lessons for the debate on the European Union.

The first section outlines the institutional evolution of the Swiss political system in the nineteenth and twentieth centuries, emphasizing how and why it moved through a series of phases. The next section describes the essential features of today's Swiss federalism, in particular the division of competences and relationship between the three levels of government. The following section compares the Swiss experience with the evolution of the EU and discusses the extent to which the comparison between Switzerland and the EU sharpens our understanding of the dynamics at play in the latter. The concluding section draws some lessons for the debate on the adoption and the ratification of the Constitutional Treaty.

\section{The Institutional Evolution of the Swiss System}

From the fourteenth century until 1848, Switzerland became a progressively tighter confederation of small states or cantons. ${ }^{3}$ This slow evolution from looser to tighter confederation was interrupted between 1798 and 1815 when the country was invaded and de facto ruled by revolutionary France, which imposed first a unitary state under the name of the Helvetic Republic and later a partial return to a confederal structure. ${ }^{4}$ Although this period is often overlooked in accounts of Swiss political history because it is seen as an alien imposition that was immediately rejected by the Swiss, it actually had a lasting effect on Switzerland's political system. The origins of two of Switzerland's peculiar features, the referendum and the 'directorial' form of executive bodies, can be traced back to this period. ${ }^{5}$ After the fall of Napoleon the Swiss cantons regained their sovereignty and, via the Federal Treaty of 7 August 1815, re-established a confederation among themselves, albeit on a tighter and more democratic basis than before 1798. This latter form of confederation lasted until 1847-48 when, following a brief civil war, it was replaced by the modern federal state. The institutional structure set up by the first federal constitution in 1848 has remained largely unaltered ever since, despite major constitutional revisions in 1874 and 1999. As discussed in the next section, however, the distribution of competences and power between the cantonal and federal levels has changed considerably.

Two periods in Swiss political history are particularly relevant for our purpose of comparing the European Union to the Swiss experience. The first one is the last confederal phase, between 1815 and 1847. In this period, the confederation reached institutional 'maturity' with a more sophisticated institutional structure and wider policymaking remit than had been the case before 1798. The second period is that of the modern federal state post-1848, especially the formative half-century after its establishment. The confederal phase lends itself to a comparison with the existing EU, on the basis of the assumption that the European Union of today is essentially a confederal political system subject to a number of pressures to become a federal state and, at the same time, facing very powerful resistances to moving down such a path. ${ }^{6}$ The experience of Switzerland as a federal state is useful as a point of comparison when considering what might occur if the EU were to become a federal state. The remainder of this section outlines the institutional structure and the political dynamics in the two periods mentioned above. 


\section{The Last Confederation: 1815-47}

The last phase of the Swiss confederation was the most institutionally elaborate and mature form of confederation in Swiss history. Despite being an explicit attempt to 'restore' the pre-1798 order, the 1815 Treaty did accept a number of innovations brought about by the French hegemony, chief among them being equal status for all territories as cantons, including those which had semi-colonial status prior to 1798 .

The confederation was thus a union of $21^{7}$ small sovereign states - cantons coming together to, in the words of Article 1 of the 1815 Federal Treaty, 'defend their freedom and independence from any foreign attack as well as preserving internal order and peace' (Kölz, 1992-96: 193). The cantons were independent and sovereign states de jure and, to a large extent, de facto although some encroachment on their sovereignty was already visible despite the essentially confederal nature of the system. This same Article 1 revealingly stipulated that cantonal constitutions were adopted by the supreme authority of each canton but also that they had to 'conform to the principles of the federal treaty', which implied that the relationship between the cantonal constitutions and the Federal Treaty was not dissimilar to the relationship existing in the EU between the state constitutions and the EU treaty. ${ }^{8}$

The institutional structure of the Confederation, which was centred on a Diet made up of representatives of each canton, was much less complex than that of either contemporary Switzerland or today's EU. Cantons were on an equal footing with each other, each having one vote regardless of the size of their population or their contribution to the confederal treasury. ${ }^{9}$ Cantonal representatives to the Diet were delegates of their respective cantonal governments and voted upon the latter's instructions. The Diet normally met annually, in July, in the capital of the so-called 'managing canton' (Vorort) whose own chief magistrate would be in the chair. When the Diet was not sitting, the general administration of the Confederation was entrusted, on a rotating biennial basis, to one of the 'managing cantons', whether Zurich, Berne or Lucerne. The managing canton would also host the skeletal confederal administration - the confederal chancellery - appointed by the Diet. The Diet normally voted on the basis of a simple majority, with the exception of very important decisions - such as military matters - for which a three-quarters 'qualified majority' was required.

In the tradition of previous confederations, this last one was also primarily concerned with defence and security, both external and internal. At the heart of the Confederation was a mutual-defence guarantee set out in Article 4 of the Federal Treaty. As there was no standing confederal army, the defence of the confederation was provided by the cantonal contingents directed in time of war by a confederal commander as general. However, the Confederation was also concerned with economic matters. It notably had the significant responsibilities of conducting external trade policy and signing commercial treaties. The Confederation also set a common external tariff that was collected by the border cantons and paid into the confederal treasury annually. This external revenue was the only independent source of income for the Confederation, which had for the rest to rely on cantonal contributions, although a 'national' debt accruing to the Confederation was recognized.

Even at this stage, the constitutional framework of the Confederation placed significant constraints on the autonomy, if not the sovereignty, of the cantons. In addition to 
the constitutional 'compatibility clause' already mentioned, the Treaty also prevented cantons from concluding alliances with each other or agreements with foreign states that were deemed to be in conflict with its norms or were detrimental to the rights of the other cantons. On the other hand, despite the emphasis on equality symbolized by the elevation of all territories to a cantonal status as declared in Art. 7, there were no provisions for confederal citizenship, with the result that citizens had rights only within their own canton and were considered 'foreigners' in all other cantons. Moreover, if the balance of power between the central level and the cantons might appear to have been rather unfavourable to the latter for a confederal order, the lack of enforcement power on the part of the central level meant that the cantons often ignored the Diet's decisions (Aubert, 1974: 18).

To conclude this briefest of outlines of the institutional structure of the last Swiss confederation, it is important to stress that cantons which signed the Federal Treaty in August 1815 could plausibly be described as sovereign states but not as nation states in the contemporary sense of the term. This is because, even if they were determined to defend their autonomy vis-à-vis encroachment from the centre, they accepted that a sense of Swiss national identity was already present, partly as a result of the impact of French revolutionary ideas and the experience of the Helvetic Republic. This sense of Swiss nationhood was explicitly mentioned in the last article of the Treaty, which made reference to the 'common fatherland' of the cantons and was also revealed by the proliferation of 'national' associations in the $1810 \mathrm{~s}$ and $1820 \mathrm{~s}$ (Kölz, 1992-96: 202; Aubert, 1974: 19).

\section{From Confederation to Federation}

The confederation established by the 1815 Federal Treaty was an explicit attempt to go back in time to the old ways of the Swiss tradition and to forget as much as possible of the revolutionary period. However, the forces unleashed by the revolution could not be kept at bay, and they put increased pressure on the institutional structure of the last confederation as it entered the 1830s and 1840s. Most of these forces were part of the broader 'liberal movement' sweeping Europe from which Switzerland could not isolate itself. Moreover, the Europe-wide battle between liberal and radical forces on one side and conservative and reactionary ones on the other also led to Switzerland's becoming an object of external pressure, particularly from Austria and France.

Politically, the rise of the liberal movement generated strong demands for greater equality, more citizen participation, clearer limits on government and, especially, more competences for the central level and a stronger institutional infrastructure to carry them out. From about 1830 onwards, this movement led to wide-ranging constitutional reforms in a number of 'progressive' cantons, which adopted new constitutions that they submitted to popular approval in a referendum (Aubert, 1974: 20). ${ }^{10}$ If in some cantons these reforms were achieved more or less peacefully, in others this was not so. In some extreme cases the confrontation between liberal and conservative forces led to bloodshed: in canton Basle it even led to the secession of the countryside to form a new half-canton, Basle Country, in 1833. ${ }^{11}$ Moreover, this atmosphere of confrontation generated inter-cantonal defensive pacts on both sides which would spell trouble for the future. 
Economically, the liberal movement manifested itself in growing demands for the creation of a unified economic space from which economic growth would greatly benefit. Under the 1815 treaty, there still existed a variety of weights, measures and currencies in Switzerland, and cross-cantonal trade was subject to tariffs and duties. Bourgeois reformers in the rapidly industrializing cantons such as Zurich came to see this economic fragmentation as one of the greatest obstacles to the nation's progress. Hence, they added their weight to the pressures for a centralization of the system (Fahrni, 2003: 63-76; Lister, 2001: 111).

The reform movement inevitably spilled over - or, more accurately, up - from the cantonal to the confederal level, with the liberal and radical members of the Diet exercising pressure on their conservative counterparts for a reform of the Federal Treaty in a more centralist direction. A project along those lines in 1832-33 failed to achieve consensus, with the progressive cantons finding it too timid and the conservative ones too radical. The failure of such moderate reforms had the effect of emboldening the radical wing of the liberal movement, which thus intensified its campaigns for radical democratic and federal reforms. In addition, social elements began appearing in the campaigns. The forces of liberalism and radicalism on the one hand and of Catholic conservatism on the other balanced each other out, with ten or so cantons on each side, and the delicate equilibrium at the confederal level could suddenly be altered by revolutions and counter-revolutions in some cantons, most notably that in Lucerne, which overthrew the liberal government there in 1841. These background trends were further exacerbated in the late 1840s by several disputes that touched on delicate issues such as the presence of religious orders in the Catholic cantons.

In this climate, the Catholic cantons felt threatened by the mounting radical tide and in December 1845 they signed a pact of mutual support known as the Sonderbund. Under the terms of the Federal Treaty such pacts were illegal, hence the existence of the Sonderbund was initially kept secret. The pact became public, however, in June 1846, triggering an immediate demand by the liberal cantons for its annulment. At that time, however, the liberals and radicals did not constitute a majority in the Diet. They did achieve a majority a year later, after the cantonal elections in Geneva and St Gallen, so the Diet, meeting in July 1847, decided to dissolve the Sonderbund, to expel the Jesuits and to revise the Treaty in a more centralist direction. These decisions triggered a month-long civil war which ended in the defeat of the conservative, Catholic cantons of central Switzerland and in the triumph of the radical forces (Remak, 1993). ${ }^{12}$

These liberal cantons set up a constitutional commission entrusted with a 'revision' of the Treaty, but, as it turned out, they ended up drafting a constitution for a federal state thereby radically changing the nature of the Swiss political system. In June 1848, the new constitution was endorsed by the Diet, with 13 votes in favour and 9 against or abstaining. Subsequently, the new constitution was ratified by popular referendum in all but one of the cantons, with 13 and a half votes in favour and 6 and a half against. In September the last Diet gathered to promulgate the new constitution and establish the new federal state, although, strictly speaking, the procedures by which the new constitution was being adopted were illegal under the terms of the existing Federal Treaty. The cantons defeated in the civil war voted against the new constitution both at the Diet and in the ratification process but ultimately accepted the outcome and 
participated in the subsequent election for the new federal parliament. The new parliament gathered for the first time in November 1848 in Berne, which was made the permanent capital.

\section{The 1848 Settlement}

The 1848 constitution represented a compromise settlement between the vision of the radicals and the need to keep the old Sonderbund cantons on board. It set up a federal state in which the cantons retained ample autonomy in many areas of policy-making under the 'residual powers' clause of Art. 3. In formal constitutional terms, the shift from a confederation of states to a federal state was far from unambiguous. On the one hand, the first article of the constitution cited as the constituting body of the new state 'the peoples of the twenty-two sovereign cantons', with no mention of a single Swiss demos. Moreover, no explicit supremacy clause of federal law over cantonal law was written into the constitution. ${ }^{13}$ On the other hand, the preamble made explicit reference to the 'unity, force and honour of the Swiss nation' and Art. 3 clearly stated that cantons were sovereign only insofar as their sovereignty was not specifically limited by the federal constitution. ${ }^{14}$ As had been the case in the past, however, political practice was different from the letter of the constitution and pointed to a clear shift of power towards the central level. Despite an initial challenge to the legality of the new constitution by three members of the defeated Sonderbund Uri and the two half-cantons of Nidwald and Obwald ${ }^{15}$ - direct defiance of the principle of federal sovereignty in the formative period of the new state was very rare, and there is substantial evidence that the principle was widely accepted by cantonal authorities, despite their insistence on describing their cantons as 'sovereign states' (Goldstein, 2001: 99-140).

The change between the pre- and post-1848 constitutional order was not much more dramatic in terms of policy-making competences conferred to the federal level although, as explained below, these were explicitly spelled out in the constitution and made subject to the procedure for constitutional revision. There was still no single, standing federal army, no direct federal taxation and no unified civil and criminal legal codes. ${ }^{16}$ The clearest innovations were in the field of the management of the economy and citizenship rights. In the former, the constitution established a single economic and monetary space with the federal authorities in charge of enforcing it. All discrimination in inter-cantonal trade was abolished, the federal competence in external trade confirmed and a single currency established. The constitution also created Swiss citizenship, giving citizens the ability to exercise their rights throughout the federation regardless of their canton of residence. ${ }^{17}$

The crucial difference from the previous constitutional order was arguably in the institutional framework of the system. Whereas under the 1815 Federal Treaty the only real confederal institution was the non-permanent Diet, the 1848 Constitution set up an elaborated set of federal institutions - partially modelled on the US system - with a bi-cameral Federal Assembly, a seven-member executive called the Federal Council and a Federal Tribunal. The Federal Assembly was made up of a directly elected lower chamber (the National Council) and an upper chamber of cantonal representatives (the Council of States) in which each canton was represented by two 
members, irrespective of its population. ${ }^{18}$ Each chamber had exactly the same power, thus giving cantons strong influence in federal decision-making. Even more importantly, from the cantons' point of view, was the fact that the granting of new policy-making competences to the federal level would only be possible on the basis of a constitutional revision, which was made dependent on an endorsement in a referendum by a majority of the people and of the cantons.

Wide cantonal autonomy in policy-making, equal representation at the federal level, perfect bicameralism and a cantonal majority for constitutional revisions thus represented a formidable set of guarantees to the cantons - especially to those on the losing side of the 1847-48 confrontation - that the minority would not be trampled on in the new federal state. Their position was later consolidated by the growing use of direct democracy and proportional representation. This probably goes a long way towards explaining the acceptance of the new order and the remarkable stability of the modern Swiss political system. Despite two constitutional revisions, in 1874 and 1999, today's institutional framework is still essentially the one set up in 1848.

\section{The Evolution of Swiss Federalism Since 1848}

If the 1848 settlement represented a delicate compromise between the desires of the liberal and radical majority and the fears of the conservative minority, it could not for long resist new pressures from both the liberal-radical movement and economic necessity. As we have already seen, the new federal state was still extraordinarily decentralized, with limited competences exercised at the central level. The pressures that had led to the transformation of the confederation into a federal state were now pushing in the direction of a greater centralization of the latter. The main drive was the desire to harmonize regulations across cantons, especially weights and measures and the legal codes, in order to facilitate economic activity on a country-wide basis. After a failed attempt in 1872, a wide-ranging constitutional revision was approved in 1874 giving more power to the central level, notably on matters of defence, private law, transport and the environment.

As noted above, the 1874 revision left the institutional structure largely unchanged, with the significant exception of a strengthening of the powers and independence of the Federal Tribunal. In fact, the most significant innovation of the new constitution was the introduction of an optional referendum for ordinary legislation, whereby 30,000 citizens could challenge any law passed by the Federal Assembly, adding to the mandatory referendum for constitutional revisions. Even more important in this respect was the introduction, in 1891, of the popular initiative for partial constitutional amendments. ${ }^{19}$ These instruments became the pillars of the system of direct democracy that has profoundly shaped the Swiss political system. In particular, as discussed in more detail below, direct democracy has played a crucial role in constraining the centralizing tendency of the political dynamics and thus has preserved some of the peculiar features of Swiss federalism.

This slow but persistent centralizing tendency was clearly displayed where the harmonization of legal codes was concerned. An 1898 constitutional revision paved the way for the adoption of a single civil code in 1907 and a single penal code in 1937 . After the First World War, and even more so after the Second World War, the same 
centralizing dynamic was on display in the progressive creation of a welfare state, with more and more power conferred to the central level. This trend was reflected in the fact that the 1874 constitution was amended more than 100 times over the course of the following century (Church, 2004: 35-47). Some of the most conservative cantons, such as Uri, have consistently voted against all full, and most partial, revisions of the constitution since 1848 but have nonetheless never questioned - after the very initial challenge - the legitimacy of the system. Interestingly, and probably not unrelated, official nation-building after 1848 was centred on the 'myths' (such as the 1291 oath and the William Tell legend) of the 'primitive' Switzerland of the so-called Forest Cantons - the small, rural, conservative, Catholic cantons which fought and lost a civil war to prevent a unified state from seeing the light of day. ${ }^{20}$

From before the establishment of the federal state until the 1970s, a slow but unambiguous process of centralization thus took place in the Swiss federal system. It was, moreover, a process that gathered momentum over time, with a decline in the number of defeats to constitutional amendments from the end of the nineteenth century onwards (Aubert, 1974: 86). However, it is important to nuance this statement. First, the Swiss federal state started from a situation of extreme decentralization more commonly associated with confederations than with federations. The power shift that has occurred over time can then partially be explained by the very low initial level of centralization. Secondly, centralization has largely been confined to legislation while policy implementation has been left to the cantons and the communes. Hence, for example, while legal codes have been harmonized, the organization of the judicial system is still in the hands of the cantons. Thirdly, centralization in the Swiss system, though significant, has not gone as far as it has done in other federal states, with the result that Switzerland is still the most decentralized of the main federations (McKay, 2001: 142).

The process of centralization over time has been driven by three main forces: the desire to facilitate economic activity by creating a single economic space governed by harmonized regulation; the desire to grant citizens equality of rights in the political and social spheres, which has translated into the strengthening of Swiss citizenship and the building of a welfare state; and a strong nationalist ethos in the Radical Party. In political terms, the forces driving this process forward were thus what could be broadly defined as the 'left', which meant in the nineteenth century the liberaldemocratic movement embodied by the Radical Party, and in the twentieth century the latter allied, to a certain extent, with the socialist movement. The forces resisting it were essentially the conservative, Catholic party primarily rooted in Germanspeaking, central Switzerland and the liberal free-market forces of French-speaking Switzerland.

Beyond this fairly conventional positioning of the political forces on the issue of relative distribution of power between the federal and the cantonal level, however, centralization has also been constrained in Switzerland by a number of factors more peculiar to the Swiss political system and culture. The first and most obvious one is the presence of strong cantonal identities rooted in history and normally associated with linguistic and religious traits. Although these identities are subordinate to an overall sense of Swiss nationhood, they make cantonal governments and, importantly, their populations - who have the final say on constitutional amendments - wary of 
allowing policy-making competences to drift away to the federal institutions in Berne. Secondly, centralization has been restrained by the quintessentially Swiss belief that 'local' is always preferable in principle to 'distant', and thus that policy-making should be conducted, as much as practical, at the lowest possible level. It is in essence the spirit of the much-debated principle of subsidiarity, even though the principle was not explicitly spelled out in the Swiss constitution until $2004 .^{21}$ The lowest possible decision-making level in Switzerland is, of course, that of the people as embodied in the modern institutions of direct democracy and in the tradition of the Landsgemeinde or popular citizen assemblies. ${ }^{22}$

This leads us to the last, but by no means least important, factor that has constrained centralization in the Swiss federal system: the constitutional framework. Federal competences must have an explicit constitutional basis, hence each new transfer of competence requires an amendment to the constitution. Furthermore, any such amendment must pass the ultimate test of the mandatory referendum with double popular and cantonal majorities. Many constitutional amendments have foundered in the face of popular opposition. Taken together, these factors peculiar to the Swiss system have posed a formidable obstacle to the process of centralization, and yet centralization has still been significant. Relative centralization of legislation and regulation over time and the maintenance of decentralized policy implementation has brought about a wholesale blurring of the division of competences between the two levels of government, thus undermining the original vision of the founding fathers of the federal state.

\section{Contemporary Swiss Federalism}

Two general points should be made about Swiss federalism. First, it is not a fixed entity but an evolving affair marked by constitutional change and driven by political dynamics. Secondly, its contemporary form and how it functions are not only matters of institutional mechanics and of formal division of powers. They are also intimately linked to political culture in a much more organic and behavioural way. More generally, federalism is still vigorous both in its 'institutional' and 'cultural' forms and remains very much at the heart of the Swiss political system. If anything, the 1999 Constitution has reinforced it by, for example, making for the first time an explicit reference to the role of the communes in Art. 50. It is also worth emphasizing that in Swiss political discourse, federalism implies decentralization so that if someone says they are a federalist, they mean pro-cantons and anti-Berne. ${ }^{23}$ This understanding of federalism contrasts sharply with that prevailing in the British discourse on the EU, especially in Eurosceptic quarters.

At heart, Swiss federalism is concerned with giving as much autonomy as possible to local communities and letting the differences between them coexist peacefully and harmoniously. Moreover, beyond the formal institutional arrangements, it is a way of working and thinking, shaped by history and rooted in an organic, bottom-up conception of the state. In such a context, informal institutions and procedures are as (or more) prominent than formal ones. Swiss federalism has grown into a form of cooperative federalism where there is a functional division of competences between the federation and the cantons rather than a dualistic separation: legislation largely produced centrally; implementation largely done regionally or locally. ${ }^{24}$ The principle 
of loyal co-operation between levels of government - the so-called Bundestreue obligation - is central to its working and is reflected in the tax system which is also divided both vertically and horizontally. Finally, it is important to point out that because of its depth and width in Swiss society, federalism has become a key component of Swiss national identity, which is based on 'constitutional patriotism' rather than, of course, on shared ethnicity or culture. ${ }^{25}$

This 'mythical' role probably also accounts for a certain anachronism in the official terminology applied to Swiss federalism, with the state still officially called a confederation and many cantons still describing themselves as independent, sovereign states. The rest of this section explores these aspects by looking at actors, constitutional provisions, formal and informal rules and procedures, and, finally, the problems and wider applicability of Swiss federalism. It will conclude that Swiss federalism is more complex and behaviourally determined than is commonly realized, partly because of direct democracy, and that this raises questions about the extent to which the Swiss experience is transferable.

\section{Actors}

There are three sets of institutional actor in Swiss federalism: the federation, the cantons and the communes. All three levels of government have specific constitutional tasks though their nature and extent naturally vary - and it is critical to include the communes because they play an essential role in Switzerland.

The cantons still appear to be the central actors. Not only are they the crucial middle level between the federation and the communes, they are also the building blocks of the state. Constitutionally, they are the only actors free to determine their own policymaking role within the limits of the federal constitution although, de facto, this freedom has been progressively reduced by the process of centralization discussed above. Moreover, as already mentioned, they are the main agencies of public policy implementation in the country and thus the principal 'face' of the political system vis-à-vis the citizens.

The 26 cantons and half-cantons vary greatly in size, both geographically and demographically, in their political influence and in the length of time they have been in the Swiss (con-)federation but, nonetheless, they all have the same rights under the federal constitution. ${ }^{26}$ So-called half-cantons, the result of splits of whole cantons at critical historical junctures, are almost de facto full cantons and have the same rights save for having just one seat, rather than two, in the Council of States and half the weight in calculating the cantonal majority in constitutional referendums; the 1999 Constitution further plays down the distinction between full and half cantons. Cantons, as already observed, still tend to perceive themselves, at least in their official discourse, as independent and sovereign. Indeed, they do retain vestigial elements of statehood including a concept of cantonal demos and citizenship, full taxation power and a 'residual powers' clause. They are probably more autonomous, more organic and more 'self-conscious' than regional units in other federal systems. ${ }^{27}$ Partly because of their historical independence and 'precedence' vis-à-vis the federal state, cantons are also more inclined to act as individual units rather than as a collective 'cantonal lobby'. Historically, the cantons have preferred to retain their policy-making autonomy 
rather than to cede it to the central level in exchange for a significant stake in federal decision-making, although, in some areas, they have inevitably been forced to do so and are now fully integrated into federal decision-making. Not only are they represented in one chamber of the bi-cameral Federal Assembly, they are also fully involved in pre-parliamentary consultations on draft legislation, a crucial agenda-setting phase in the Swiss law-making process (Church, 2004: 163-86).

The federation is, nevertheless, a very important actor, although, strictly speaking, its status is ambiguous. At some points, the federal constitution implies that the 'Confederation' - i.e. the federation - is synonymous with the whole Swiss political system, including cantons and communes. Elsewhere, it refers to the 'Confederation' as the federal level of government - essentially the federal institutions - as distinct from, if not sometimes opposed to, the cantons and the communes. While bearing in mind the tension between the two conceptualizations, we use the latter conceptualization not least because one key component of the 'Confederation', both in the formal language of the constitution and, in a very real sense, through direct democracy, is the Swiss people, who cannot be neatly subsumed into the federal institutions. ${ }^{28}$

Communes are also important actors in the system. There are several types of commune, but the one we are concerned with here is the so-called 'political commune', comparable to those in Germany, France and Italy (it does not have an exact equivalent in English local government) (Church, 2004: 92-102). The nearly 3000 communes carry out a great deal of policy implementation, directly raise a significant amount of taxation to finance it and, importantly, are the agencies granting citizenship. Uniquely among federal states, Swiss citizenship depends on cantonal citizenship which in turn depends on citizenship of a commune. ${ }^{29}$ It is tempting to see communes as miniature cantons, and there are certainly many similarities between the two. However, it is worth pointing out that cantons are not themselves 'federal' so do not accord communes the status the federation accords to them. Nonetheless, many cantons make explicit reference to the communes in their constitutions and treat them with a great deal of respect, unlike the cavalier way local government is treated in some other political systems. The 1999 constitution also gives formal recognition to communes and requires the federal institutions to take them into account when formulating public policy.

\section{Division of Competences}

The division of competences between the three levels of government is primarily regulated through constitutional norms: federal norms regulate the relationship between the federation and the cantons, and cantonal norms regulate the relationship between canton and communes. The new constitution adopted in 1999 ushered in some slight changes. As these new rules have been in operation for such a short time, it is not possible to evaluate their impact fully. The presence of constitutional rules at both federal and cantonal level means that each of the three levels operates within legal constraints and has to respect the autonomy and prerogatives of the other levels and to cooperate with them. This said, there is a clear hierarchy of levels. Cantonal constitutions and legislation constrain the communes' margin of manoeuvre while the federal constitution and laws prevail over cantonal laws. Importantly, cantonal acts are subject to 
judicial review by the Federal Tribunal while federal acts are not and can only be challenged through referendum.

The formal division of competences is less clear-cut than might be expected: it is not fully specified and it operates through several categories - fully cantonal, joint, and fully federal - which are not straightforward. The complexity arises from the fact that the joint competences are shared between the two levels in a variety of different ways and that even within fully federal competences policy implementation is typically left to cantons and communes. In other words, the division of competences relates essentially to the legislative sphere, while policy implementation is overwhelmingly carried out at lower levels. (Appendix 1 gives a more detailed picture of the division.)

By and large, this pattern is mirrored in the fiscal sphere. All three levels have revenue-raising powers and broadly speaking aim to be self-financing although there is a considerable degree of revenue sharing. Reflecting the distribution of policy implementation, cantons and communes spend more than the federation; indeed, the federation has been granted tax income on a limited temporal basis only and cannot extend it unilaterally. Although not dependent on income from the centre, cantons do get help from the federation through sharing in federal taxes plus by receiving grants, refunds and subsidies in compensation for their implementation role and/or investment. This is done through an equalization fund intended to smooth the imbalances in revenues among cantons. However, significant differences persist and the overall financial impact of equalization is much weaker than in other federal systems, such as Germany. It is, however, comparable to the EU structural funds in relation to GDP (McKay, 2001: 115). There is an ongoing debate on how to streamline the equalization system notably on the possibility of turning it into a purely horizontal system of transfers between 'rich' and 'poor' cantons, by-passing the federal level (Church, 2004: 92-102).

\section{Institutions and Formal Procedures}

The three levels - and especially the cantons and the federation - are woven together in a cooperative way by a variety of means, including:

- Constitutional amendments: cantons have collective veto power over any shift of competences to the federal level because all amendments to the federal constitution are subject to approval by a majority of cantons, as well as of the people, in a mandatory referendum. It does happen that popular and cantonal majorities do not coincide and thus that amendments are not passed; eight such occasions have occurred since 1848 (Church, 2004: 143-53).

- Political representation: theoretically this takes place via the Council of States, which, as mentioned above, has equal power with the National Council. With the shift to direct elections, members are now elected on party lines and owe greater loyalty to their party than to their canton. However, cantons also serve as constituencies for elections to the National Council so the cantonal basis of representation remains strong. ${ }^{30}$ The role of representation of the cantons is to a certain extent performed by the intergovernmental conferences of cantonal ministers and cantonal presidents, which are the collective voice of the cantons. There is no cantonal 
representation as such in the seven-member Federal Council (the federal executive), but unwritten proportionality rules stipulate that not more than one councillor should come from the same canton and that the college should contain at least two non-German speakers and both Protestants and Catholics. ${ }^{31}$

- Decision and policy-making: cantons share in this via the Council of States, their constitutionally guaranteed role in the process of pre-parliamentary consultation, by representation in federal bodies such as the Integration Bureau ${ }^{32}$ and via federal-cantonal conferences. Under Art. 141 of the federal constitution a request by eight cantons can also trigger a referendum challenge to any federal law. ${ }^{33}$ Cantons are thus fully involved in the three key phases of federal law-making in Switzerland: pre-parliamentary, parliamentary and post-parliamentary.

- Implementation: as already mentioned, cantons and communes undertake most of the financing and implementation of federal laws and policies: there is no local federal administration such as that which exists in the US. There is also a great deal of inter-cantonal cooperation, through conferences of ministers and signing of 'treaties', known as concordats, on a range of matters that cantons want to retain as their exclusive competence but on which some degree of harmonization is also deemed desirable. A prominent example of this is horizontal cooperation in education among the francophone cantons. ${ }^{34}$

- Judicial: cantonal courts provide the lower level of the judicial system. Legal codes have now been harmonized at the federal level although the organization of the judicial system is still left to the cantons, with significant differences existing between them. Apart from the Federal Tribunal and its specialist sections, there is no overall federal judicial system. The Federal Tribunal ensures uniform application of federal law and compliance of cantonal acts with it. However, as it is not a constitutional court, it does not have the power to strike down federal acts on the grounds of unconstitutionality. Moreover, the 'guaranteeing' of cantonal constitutions' conformity with the federal constitution is performed by the Federal Parliament not by the Tribunal.

\section{Informal Behaviour and Politics}

Informal behaviour and political culture broadly understood are important to Swiss federalism. All Swiss institutions such as parties, trade unions, business associations or voluntary associations are organized in a federal way, bringing together cantonal and other decentralized branches. This depth and spread of federalism as an organizing principle of political life emerges from shared historical experiences and identities and feeds into a political culture which very much values autonomy and bottom-up solutions. The Swiss tend to express this as 'feeling federal'. The way federalism totally pervades Swiss political life is very much in evidence in the democratic process itself, be it through the representative institutions or through direct democracy. Parties that operate at the federal level are federations of cantonal parties rather than centralized organizations; hence they usually have a significant degree of internal political differences. The split in the right-wing Swiss People's Party (SVP) between the traditionally conservative Bernese wing and the much more radical Zurich wing is the most emblematic example (Kriesi, 2001). There are also subtle and 
not-so-subtle linkages between cantonal and federal elections with the former especially in key cantons - often interpreted as bellwethers for the latter.

Federalism is also prominent where direct democracy is concerned. Referendums and initiatives were historically introduced in cantons from the 1830s onwards before being adopted by the federation. They are still more widely used and their impact on the system is deeper at cantonal and communal level than at the federal level. All cantons have a right of legislative initiative and, unlike the federation, many use the financial referendum on important items of public expenditure (Kriesi, 1998: 90-98). Much the same goes for the communal level. Thus, the greater part of citizen participation in decision-making in Switzerland - through direct democracy - takes place at the cantonal and communal levels rather than at the federal level. It is also worth stressing that the cumulative impact of direct democracy across the three levels is huge and makes the Swiss system extraordinarily open to citizens' input.

\section{Problems}

All this may seem to suggest that the system is wonderful and faultless; it is indeed often highly praised. But, although most people would agree that, generally speaking, it works well, there are problems. It is subject to strong centripetal forces which suggest that some of its outcomes are not optimal. A list of the most prominent issues would include:

- Territorial: most of the cantons, and especially the half-cantons, are very small by the standards of European regions, some of them extremely so. AppenzellInner-Rhoden, to cite the most obvious example, has an area of 172 square $\mathrm{km}$ and a population of 14,500 . Due to their limited size, and often irregular borders, these small cantons are simply not effective as 'functional' administrative units. There has been a movement towards using larger 'group of cantons' units for statistical purposes, but any suggestion of mergers of cantons is extremely sensitive. Attempts to reunify the two halves of canton Basle and to merge Geneva with Vaud foundered after lengthy negotiations and amid public hostility. Needless to say, what makes the cantons what they are is their historical identities as distinctive 'patries' rather than administrative rationale, so any attempt to restructure the cantonal level of government by appealing to the latter tends to be a political non-starter.

- Transparency: the blurring over time of the division of competences and of responsibilities makes the process of decision-making rather opaque. A recent attempt to disentangle it has had only limited success (Church, 2004: 154-62). This reinforces the fact that devising a rational and effective 'division of labour' between the different levels of government and, a fortiori, an efficient system of 'fiscal federalism' is far from easy. ${ }^{35}$ The current system of financial equalization is very difficult to understand and is hard to reform given the vested interests at play and the tendency by each level of government to offload onerous tasks onto another. Tax competition among cantons is also a delicate issue, difficult to tackle without some form of fiscal harmonization which would, of course, impinge on fiscal autonomy of the cantons.

- Language: in the past federalism was an effective way of allowing different communities to live in relative isolation, thereby reducing friction. It is less able 
to do so now as the media tend to reinforce the boundaries between linguistic communities - which, with the partial exception of Ticino, ${ }^{36}$ do not coincide with cantonal borders - and no political structure corresponds to the linguistic communities. ${ }^{37}$ Although the linguistic cleavage is not directly politicized, it looms large on several key issues, including European integration.

- Status: though conservatives defend federalism as a fundamental part of Swiss identity, generally speaking it is not as popular as it used to be. Support has fallen from 60 to 40 per cent over the last ten years as criticism of some of its aspects has grown (Church, 2004: 154-62). The breaching of the informal rule that no more than one member of the Federal Council should come from a single canton that arose following the 2003 election, when two Councillors from Zurich were chosen, suggests that 'federal' considerations had been swept aside by partisan Realpolitik.

- Conservative bias: the system tends to be seen, at least from a left-wing point of view, as having a conservative bias. By empowering the rural, conservative cantons of primordial Switzerland (Urschweiz) and/or contrarians (Neinsager) it blocks progressive legislation and encourages social inequality.

- Tasks: Swiss federalism can lead to public policy tasks being tackled at the wrong level. This can be dramatically exposed in times of emergency such as the Schweizerhalle disaster when major pollution of the Rhine had to be dealt with by canton Basle-City, which clearly lacked the resources to do it. The problems canton Geneva faced in policing the anti-G8 demonstrations in 2003 is another example.

\section{Lessons for the $\mathrm{EU}$}

What can the EU learn from the Swiss experience? Three areas of the debate on the European Union are relevant here. First, how to conceptualize the nature of the EU system and what role states and citizens play within it, especially in relation to the states' desire to retain their sovereignty and the fragility of popular identification with Europe. Secondly, how to divide policy competences between the Union and the states so as to maximize the policy-making capacity of the system. Thirdly, how to improve its democratic quality, i.e. its responsiveness to the citizens both in terms of inputs and of accountability.

But which Switzerland should we look to as a model? To the contemporary system or to the last confederation? Given the nature of today's EU and the pattern of collective identities in Europe, the 1815-48 confederation is probably a closer model than today's federal state, but it is worth bearing in mind the factors that led to the end of the confederation and those that shaped the evolution of the post-1848 federal state.

\section{The Nature of the EU Political System}

Analysis of the Swiss political system before and after 1848 compared to that of the EU provides strong support for conceptualizing the EU as a confederation. Yet, although such descriptions have long been discussed, they are still not widely used, 
with many scholars preferring formulas such as 'quasi-federal' and sui generis. ${ }^{38}$ Conceptualizing the EU as a confederation opens up the possibility of analysing the EU in a comparative way, rather than treating it as an entirely unprecedented form of political system. There is one problem, however: all the main historical examples of confederation existed in the distant past; no confederation truly comparable to the EU exists today. We thus propose an analytical 'double act' of comparing a contemporary confederation of states - the EU - with a historical confederation of states - in this case Switzerland 1815-48 - and with a contemporary federal state - such as today's Switzerland. When comparing the EU to a historical confederation, we have to assess the incentives and constraints the system faced in the first half of the nineteenth century with the incentives and constraints generated by the modern world, although it does appear that the key element of the member states' desire to retain their sovereignty is relatively constant. When comparing the Union with a contemporary federal state, we need to take into account that in today's EU ultimate sovereignty - both in terms of its popular locus and of the institutions entrusted with exercising it in the name of the people - rests with the states rather with the Union, as does citizens' primary collective identification.

A powerful centralizing trend - from confederation to federation and from a less centralized to a more centralized federation - can be detected in the evolution of the Swiss system. This can probably be explained by the fact that federal states are unquestionably more coherent frameworks for economic activity and more efficient decision-makers than confederations of states as well as being, potentially, more democratic. ${ }^{39}$ The EU has faced and is still facing similar pressures towards more efficiency and more democracy so we should expect pressure for greater centralization to continue there as well.

However, the Swiss experience also indicates that the transition from a confederal to a federal order may take a very long period of time and may have to go through a phase of conflict to be finally accomplished. Despite the fact that the Swiss confederation became progressively tighter over time, the final transition to a federal state took place only after a civil war. ${ }^{40}$ Like nineteenth century Switzerland, turning the EU into a federal state would imply the explicit voluntary renunciation of sovereignty by the states, going beyond the current arrangement of 'pooled' sovereignty. ${ }^{41}$ This appears highly unlikely for the foreseeable future and suggests that the EU is likely to continue to integrate along incremental lines avoiding a 'big-bang' transition to a federal state, which could only be achieved through conflict. The way the Constitutional Treaty has been negotiated and will likely be ratified - increasingly dropping the federal elements and emphasizing the confederal ones - appears to confirm this interpretation.

A final point worth emphasizing in relation to the nature of the EU political system is that institutional evolution in nineteenth century Switzerland went hand in hand with change in collective identities. A federal state was eventually accepted only because a sense of Swiss nationhood was already there. However, once in place the federal state, in turn, embarked on official nation-building. It is difficult to ascertain the direction of causality between institution-building and collective identities - for example the Helvetic Republic failed institutionally but probably had a deep impact on identities - but it seems clear that the institutional evolution of the EU system should also be matched by identity-building or it will risk losing further legitimacy, even if it remains 
within the confines of a confederal order. A fortiori, of course, the emergence of a 'thicker' identification with Europe at mass public level could be the conditio sine qua non for a legitimate transformation of the EU into a federal state. ${ }^{42}$ So far there has been little sign of this happening.

\section{The Allocation of Competences}

On the issue of the division of competences, there are more differences than similarities in the way policy-making responsibilities are allocated. These differences are of two kinds: legal-constitutional and substantive. As regards the former, the EU competences rest on a principle of explicit conferral by the states while in Switzerland the federal and cantonal competences are defined by the same federal constitution. In this, as in many other respects, the contrast between the EU's confederal nature and the 'organic', federal nature of Switzerland is sharply visible. On the other hand, the principle of the supremacy of Union law over state law mirrors that of federal law over cantonal law and is formally recognized in Art. 10 of the Constitutional Treaty as it is in Art. 49 of the Swiss constitution. Much the same goes for the principle of subsidiarity which informs the distribution of power in both systems under Art. 9(3) of the Constitutional $^{43}$ Treaty and the new Art. 5a of the Swiss Constitution respectively.

Substantively, the allocation of competences appears similar in the two systems, but crucial differences are evident. ${ }^{44}$ The systems are closest in the area of monetary and fiscal policies whereby the former is dealt with at the central level and the latter is largely in the hands of the states and the cantons. As already observed, the degree of territorial re-distribution is also broadly similar. Greater divergence is present in the broad areas of transport and communication which are, by and large, run at the federal level in Switzerland but are primarily in the hands of the states in the EU. The largest discrepancy is, not surprisingly, in the area of foreign policy and defence. These are exclusive competences of the federal authorities in Switzerland, whereas they remain overwhelmingly controlled by the states in the EU (despite the provisions of the Common Foreign and Security Policy). The reforms contained in the Constitutional Treaty, including the provision of a 'double-hatted' Foreign Minister will not significantly alter the current situation. Once again, the nature of the EU as a primarily economic confederation contrasts sharply with that of today's Switzerland as a sovereign federal state.

As regards the vexed question of the 'ideal' distribution of competences in the EU, the Swiss experience indicates that this is a politically charged question and that it is virtually impossible to identify a 'perfect' distribution of competences in a neutral, 'technocratic' way. The ongoing debate in the EU on issues such as tax harmonization, as reflected in the deliberations of the Convention and elsewhere, confirms this interpretation.

Recalling the observation made above on the trend towards centralization in both Switzerland and the EU, the last point worth emphasizing is that the single most important check on centralization in the Swiss system has been the constitutional framework - in particular, the provision for mandatory referendums requiring both popular and cantonal majorities. Nonetheless, policy competences are significantly more centralized under the 1999 Constitution than they were under the 1874 
Constitution, let alone that of 1848 . This suggests that for curbing centralization, mechanisms for transferring competences are more important than the initial distribution. Constitutions are adopted at specific points in time and have to adapt to change. How they do this is crucial. In light of the above, the EU should pay as much as if not more - attention to such mechanisms than to the starting point. Moreover, it should be borne in mind that although 'constitutional' amendments require unanimity among the states in the EU, as opposed to a majority of the cantons in Switzerland, the absence of mandatory referendums in all states probably means that constitutional safeguards against centralization are currently weaker in the EU than in Switzerland. ${ }^{45}$ The decisions of several states to hold non-mandatory referendums to ratify the Constitutional Treaty may mark a shift away from this.

\section{Quality of Democracy}

As already observed, a federal constitutional order is potentially more democratic than a confederal one, and Swiss history provides ample evidence for this assertion. However, Swiss history also provides evidence that a federal order is hardly sustainable in the absence of sufficiently strong citizen identification with the federal polity as a whole rather than primarily with one of its components. Moreover, the Swiss experience, especially between 1798 and 1848, also casts serious doubt over whether the 'constitutional patriotism' hypothesis - i.e. that identification follows institutions, rather than the other way round - can work in practice, however appealing it may sound in theory.

Closely linked to the issues of democracy and accountability is the precise form of cooperation between the central level and the state/cantonal level in the two systems. Swiss federalism largely conforms to the model of cooperative federalism, whereby legislation is enacted at the central level and implementation is carried out by regional or local levels. The EU also displays many features of cooperative federalism. This form of federalism has led in Switzerland to a blurring of the responsibilities and accountability of the political system vis-à-vis the citizens. Responsibilities and accountability are already opaque in the $\mathrm{EU}$, so a deepening of the cooperative nature of the system is unlikely to improve things. A more 'dualistic' form of (con)federalism would be better adapted to the EU system and to European-wide political culture but would likely clash with the states' desire to keep power at the Union level to a minimum (Abromeit, 2002).

Finally, we cannot fully understand Swiss federalism, or indeed the system as a whole, without taking into account the role of direct democracy. The question of whether instruments of direct democracy could be used on an EU-wide basis is an extremely delicate and difficult one, which goes well beyond the scope of this article. ${ }^{46}$ Direct democracy, in various forms, has deep roots in Swiss political culture and had operated for a significant length of time at cantonal level before being adopted at the federal level; neither of these elements apply in the EU context. The Constitutional Treaty has made a step in the direction of direct democracy, however, by providing for a 'citizens' initiative' - as detailed in Art. 46, paragraph 4 - but this will not be an instrument of, strictly speaking, direct democracy because it will not lead to an EU-wide popular vote. 


\section{Conclusions}

Switzerland is an extremely interesting example of a con/federal system in both its historical and contemporary dimensions. It can be seen as the near perfect embodiment of the federal idea. But it is also a peculiar and idiosyncratic political system, in which formal institutions and cultural patterns are closely intertwined. As such it is a fascinating political system to study but also a very difficult one to imitate. $^{47}$ Moreover, recent political developments have moved the country further away from the EU and probably made the latter less willing to see Switzerland as a 'model'. ${ }^{48}$ Nonetheless, there are striking similarities between Switzerland - as a confederation and as a federation - and the European Union, both at the societal level and at the institutional level. At the societal level, Switzerland is in many respects a microcosm of Europe though, of course, the degree of 'diversity' is far greater in the EU than in Switzerland. As far as institutions are concerned, today's EU can be conceptualized as a still predominantly economic confederation facing strong and conflicting pressures - to become, and to keep from becoming, both more 'political' and more 'federal'.

As Switzerland has experienced a long confederal history and undergone a transition to a federal state, its experience could be of deep relevance for the contemporary debate on the EU. This article has sought to outline to what extent we can learn from one experience in order to shape the other. In conclusion we would argue that the Constitutional Treaty should be seen as more of a consolidation and simplification of the existing EU's confederal order than the starting point for a transition to a federal state. The division of competences between the Union and the states is likewise clarified but not radically altered and many key policy areas normally dealt with at the central level in federal states such as Switzerland remain under states' control. Though this outcome may disappoint federalists, it should not surprise anyone, not least in the light of Switzerland's experience.

\section{Notes}

${ }^{1} 1$ August 1291 is the date on which the swearing of a solemn oath between the three initial cantons of the Swiss Confederation is traditionally believed to have taken place.

${ }^{2}$ See, among others, Muret (1950).

${ }^{3}$ The country may still officially call itself a 'confederation' in Latin, French and Italian - though, importantly, not in German in which it is referred to as Eidgenossenschaft (oath fellowship) - but it is undoubtedly a federal state.

${ }^{4}$ The Helvetic Republic, imposed after the French invasion and based on the 1798 constitution, lasted until 1802. The 1803 Federal Constitution, better known as the Act of Mediation, set up a halfway system between a confederation and a federation, with France retaining ultimate authority. This lasted until 1815; see Aubert (1974: 8-16). On the Swiss executive being modelled on that of the Directorial regime in France 1795-97, see Kriesi (1998: 218-19).

${ }^{5}$ There is some disagreement among scholars on whether direct democracy should be considered a modern or a long-standing feature of the Swiss political system. On the one hand, the contemporary instruments of direct democracy were introduced relatively recently (late nineteenth century as far as the federal level is concerned). On the other hand, many cantons do have very long traditions of popular decision-making symbolized by the institution of the Landsgemeinde (open-air popular assembly) and, in certain cases, of referring decisions back to communes ad referendum.

${ }^{6}$ This point is elaborated below. 


\section{C. Church and P. Dardanelli}

${ }^{7}$ Twenty-two from 1833 when canton Basle split into two half-cantons, see below.

${ }^{8}$ European law requires that state constitutions be in conformity with its principles - e.g. the right to vote in local and European elections for EU citizens - but it has no formal power over domestic constitutions as such and offers them no guarantees.

${ }^{9}$ The latter varied from 1,184 francs from canton Uri to 91,695 francs from canton Berne at the time of the signing of the Federal Treaty, see Kölz (1992-96: 194).

${ }^{10} \mathrm{As}$ far as the cantonal level is concerned the modern form of direct democracy dates from this period.

${ }^{11}$ On the circumstances of the secession see Church (1983: 57-69).

${ }^{12}$ The country also narrowly escaped intervention by Austria and France, in support of the Sonderbund alliance and the liberal cantons, respectively; see Lister (2001: 114-16).

${ }^{13}$ This only appeared in the revised constitution of 1874 .

${ }^{14}$ Ultimately, this meant they had lost their sovereignty. There is a tendency in political science scholarship to use the term sovereignty in a loose way to mean policy-making autonomy rather than in its legal sense of ultimate, supreme power. On the cantons being no longer sovereign, see Aubert (1974: 29-30; 81). Incidentally, the supremacy of the federal constitution over the cantonal constitutions also meant that under Art. $6 \mathrm{~b}$ the latter had to have a republican nature. This could have been a problem for canton Neuchâtel, long a Prussian principality, had it not had its own republican revolution in 1848, see Aubert (1974: 33-4) and Luck (1985: 309-14). See also Art. 28 of the German constitution and Art. IV, section 4 of the US constitution for similar provisions.

${ }^{15}$ On the status of half-cantons, see Hughes (1970 [1954]: 3-4).

${ }^{16}$ Which are, of course, crucially important in a civil law system such as Switzerland.

${ }^{17}$ Interestingly, Swiss citizenship remained dependent on cantonal citizenship in a very similar manner to the way in which EU citizenship is dependent on state citizenship. Art. 42 stated: 'Everyone who is a citizen of a canton is a Swiss citizen.' Incidentally, the same article also forbade the exercise of political rights in more than one canton, unlike in today's EU where this is sometimes possible, e.g. an Italian citizen resident in the UK can vote for all elections and referendums in Italy as well as for local and European elections in the UK.

${ }^{18}$ These representatives, however, were no longer delegates of cantonal governments but were selected by cantonal parliaments. They are now directly elected.

${ }^{19}$ This allowed citizens to propose changes to individual articles of the constitution.

${ }^{20}$ The Swiss national day, 1 August, commemorates the 1291 pact rather than any date related to the foundation of the federal state. It was first celebrated in 1891; the William Tell monument in Altdorf, Uri was erected in 1895.

${ }^{21}$ It is often stated that 'residual powers' clauses such as those of Art. 3 of the Swiss constitution, Art. 30 of the German constitution, the 10th amendment to the US constitution etc. represent a formulation of the principle of subsidiarity. However, this is incorrect as they only state a presumption in favour of the cantons, Länder and states vis-à-vis the federal level but not a general presumption in favour of the lowest level of government which, in all these cases, would be the commune or municipality; see Art. 1 of the EU Treaty and Art. 5a of the Swiss Constitution introduced in 2004.

${ }^{22}$ For an enthusiastic, journalistic account of the Swiss belief in the wisdom of the people, see Føssedal (2002). Only two cantonal, Landsgemeinden survive (in Appenzell-Inner-Rhoden and Glarus) other cantons having abolished theirs.

${ }^{23}$ This is similar to the case in the United States, where 'federalism' is often linked to the idea of states' rights.

${ }^{24}$ For more on cooperative federalism, see Börzel's article in this volume.

${ }^{25}$ It could be argued that such belief in the political values of Switzerland and pride in its institutions constitute a cultural element shared by all Swiss, see Church (2004).

${ }^{26}$ In official Swiss usage, cantons are listed in descending order by the date they joined the confederation/ federation, save for the three 'managing cantons' under the 1815-48 Confederation, which are listed first.

${ }^{27}$ We prefer the term 'region' to that of 'state' when referring to sub-central units of a federal system which take different names in different countries e.g. cantons, Länder, provinces, states and indeed regions - as it avoids the conceptual confusion generated by the fact that the federal state itself is 
a 'state'. As Aubert (1974: 81) put it: 'L'Etat fédéral ou fédératif (Bundesstaat) est un Etat souverain, composé d'Etats qui ont cessé de l'être'.

${ }^{28}$ There is arguably a similar tension in the European discourse between the conceptualization of the EU as the whole political system including states, regions etc. and identifying it with 'Brussels'.

${ }^{29}$ The ruling by the Federal Tribunal in mid-2003 that communes could not use direct democracy to decide on individual applications for naturalization caused anger in conservative circles.

${ }^{30}$ It could be argued that the only real difference between the National Council and the Council of States is in the lower 'district magnitude' of the latter, which favours the centrist parties and under-represents left- and right-wing factions.

${ }^{31}$ Before 1999 , Art. 96 of the 1874 constitution formally prevented any two councillors coming from the same canton from being elected, see Hughes (1970 [1954]: 107-8). The rule was broken in the 2003 elections, when two councillors from Zurich, the largest and most powerful canton, were elected.

${ }^{32} \mathrm{~A}$ federal body charged with coordination of European integration policy.

${ }^{33}$ This happened for the first time in 2003-4 when a large group of cantons decided to challenge the Federal Council's proposed financial reforms and won.

${ }^{34}$ See Hega (2000). Inter-cantonal cooperation in Switzerland can be seen as the functional equivalent of what in the EU is now called the 'open method of co-ordination'.

${ }^{35}$ The experiences of other federal states provide ample demonstration of this difficulty. See, among others, McKay (2001: Chapter 8).

${ }^{36}$ Save for small Italian-speaking communities in Graubünden, Ticino de facto coincides with Italianspeaking Switzerland.

${ }^{37}$ For a discussion of the linguistic communities in Belgium, see Swenden in this volume.

${ }^{38}$ See, among others, Taylor (1975), Wallace (1982) and, especially, Forsyth (1981). See also Warleigh (1998) for a recent plea in favour of the same approach.

${ }^{39}$ Provided that there is a sufficient sense in the population of being a demos. So-called 'sovereignists' would, of course, contest this.

${ }^{40}$ It could be argued that the US too became a real federal state only after the 1861-65 civil war. See, among others, Goldstein (2001: esp. 22-33).

${ }^{41}$ Incidentally, in light of the Swiss, German and US constitutions mentioned above, an EU federal state with a republican order - say, a Federal Republic of Europe - would probably imply the abandonment of the monarchical order by its component states, such as the UK, as the latter would conflict with the republican principles set in the federal constitution.

${ }^{42}$ See Zimmer (2003: 85-118) and Lister (2001: 116-17) for discussions of this point in relation to Switzerland; and Forsyth (1981: 187) and McKay (2001: 145-50) in relation to the EU.

${ }^{43}$ The principle of subsidiarity was first introduced in the Maastricht Treaty.

${ }^{44}$ See Dubey (2002) for a very detailed comparative analysis of the allocation of competences in Switzerland, and in the EU (prior to the Nice Treaty).

${ }^{45}$ See also McKay (2001: 147-9) on this point.

${ }^{46}$ For recent attempts to tackle this question, see Abromeit (1998), Hug (2002) and Papadopoulos (2002).

${ }^{47}$ See Steinberg (1988) for a general discussion.

${ }^{48}$ The 2003 elections for parliament and the executive were a triumph for the right-wing Swiss People's Party, which is strongly opposed to EU membership. Although the country's application has not been formally withdrawn, the chances of it being 'activated' have further receded. Moreover, the traditionally more 'pro-EU' French-speaking part of the country also appears to have cooled considerably on the issue.

\section{References}

Abromeit, Heidrun (2002), Contours of a European Federation. Regional and Federal Studies, 12(1), pp.1-20.

Abromeit, Heidrun (1998), Democracy in Europe: Legitimising Politics in a Non-State Polity (New York: Berghahn Books).

Aubert, Jean-François (1974), Petite histoire constitutionnelle de la Suisse (Berne: Francke).

Church, Clive (1983), Europe in 1830: Revolution and Political Change (London: Allen \& Unwin). 


\section{C. Church and P. Dardanelli}

Church, Clive (2004), The Politics and Government of Switzerland (Basingstoke: Palgrave).

Dubey, Bernard (2002), La répartition des compétences au sein de l'Union européenne à la lumière du fédéralisme suisse (Basle: Helbing \& Lichtenhahn).

Fahrni, Dieter (2003), An Outline History of Switzerland - From the Origins to the Present Day (Zurich: Pro Helvetia).

Forsyth, Murray (1981), Unions of States - The Theory and Practice of Confederation (Leicester: Leicester University Press).

Føssedal, Gregory (2002), Direct Democracy in Switzerland (New Brunswick, NJ: Transaction).

Goldstein, Leslie Friedman (2001), Constituting Federal Sovereignty - The European Union in Comparative Context (Baltimore, MD: Johns Hopkins University Press).

Hega, Gunther (2000), Federalism, Subsidiarity and Education Policy in Switzerland. Regional and Federal Studies, 10(1), pp.1-35.

Hug, Simon (2002), Voices of Europe - Citizens, Referendums and European Integration (Lanham, MD: Rowman \& Littlefield).

Hughes, Christopher (1970 [1954]), The Federal Constitution of Switzerland (Westport, CT: Greenwood Press).

Kölz, Alfred (1992-6), Quellenbuch zur neueren Schweizerisches Verfassungsgeschichte, 2 vols (Berne: Stämpfli).

Kriesi, Hanspeter (1998), Le système politique suisse (Paris: Economica).

Kriesi, Hanspeter (2001), The Federal Parliament: the Limits of Institutional Reform. West European Politics, 24(2), pp.59-76.

Lister, Frederick (2001), The 'New' Swiss Confederation, in idem, The Later Security Confederations (Westport, CT: Greenwood Press).

Luck, James Murray (1985), History of Switzerland (Palo Alto, CA: The Society for the Promotion of Science and Scholarship).

McKay, David (2001), Designing Europe - Comparative Lessons from the Federal Experience (Oxford: Oxford University Press).

Muret, Charlotte (1950), The Swiss Pattern for a Federated Europe, in Edward Earle (ed.), Nationalism and Internationalism (New York: Columbia University Press).

Papadopoulos, Yannis (2002), Peut-on imaginer d'organiser des référendums à l'échelle européenne et à quelles conditions? Policy paper No.2, Paris: Notre Europe, accessed at http://www.notre-europe. asso.fr/fichiers/papadopoulos.pdf.

Remak, Joachim (1993), A Very Civil War: the Swiss Sonderbund War of 1847 (Boulder, CO: Westview Press).

Steinberg, Jonathan (1988), Imitation of Switzerland: Historical Reflections, Government and Opposition, 23(1), pp.13-30.

Taylor, Paul (1975), The Politics of the European Communities: the Confederal Phase, World Politics, 27(3), pp.346-7.

Wallace, William (1982), Europe as a Confederation: the Community and the Nation-State, Journal of Common Market Studies, 21(1-2), pp.57-68

Warleigh, Alex (1998), Better the Devil you Know? Synthetic and Confederal Understandings of European Unification, West European Politics, 21(3), pp.1-18.

Zimmer, Oliver (2003), A Contested Nation: History, Memory and Nationalism in Switzerland (Cambridge: Cambridge University Press). 


\section{Appendix 1}

Division of Competences under the 1999 Federal Constitution

\begin{tabular}{|c|c|c|}
\hline Cantonal & Joint & Federal \\
\hline & Fully Shared & \\
\hline Culture (Article 69) & Agriculture (104) & Foreign Policy (54 \&184) \\
\hline Policing (52) & Energy (89) & Army \& Defence $(58-60)$ \\
\hline Youth \& Sport (68) & Internal Security (57) & Customs (101) \\
\hline Education (70) & Sustainable Development (73) & Alpine Traffic (84) \\
\hline Church/State & Economic Life (94) & Provisioning (102) \\
\hline Relations (72) & Taxation (128) & Foreigners (121) \\
\hline \multirow{2}{*}{$\begin{array}{c}\text { Cultural \& National } \\
\text { Heritage (78) }\end{array}$} & Water Resources (76) & Naturalization (38) \\
\hline & Civil \& Criminal Law (122-3) & Swiss Abroad (40) \\
\hline \multirow[t]{26}{*}{ Culture (Article 69) } & Political Rights (39) & Armaments (107) \\
\hline & Social Security (41) & Rail \& Air Travel (87) \\
\hline & Pensions etc $(111-112)$ & Road Taxes $(85-86)$ \\
\hline & & Alcohol (105) \\
\hline & Federal legislation and & Gambling (106) \\
\hline & cantonal implementation & Nuclear Power (90) \\
\hline & Environmental Protection (74) & Competition (96) \\
\hline & Land use planning (75) & Public Works (81) \\
\hline & Health \& Health Insurance (118) & Economic Policy (103) \\
\hline & Commerce \& Industry (94-95) & Consumer Protection (97) \\
\hline & Footpaths (88) & Banking (98) \\
\hline & Animal Protect (82) & Statistics (65) \\
\hline & Road Traffic (83) & Forests (77) \\
\hline & Civil Defence (61) & Voc. Education (63 \& 67) \\
\hline & Transport (87) & Monetary Matters (99) \\
\hline & Company Pensions (113) & \\
\hline & Maternity \& Family (116) & \\
\hline & Accident Insurance (117) & \\
\hline & Genetic Policy (119-20) & \\
\hline & Federation only aids & \\
\hline & Research (64) & \\
\hline & Training (68) & \\
\hline & Sport (68) & \\
\hline & Labour (110) & \\
\hline & Leasehold (109) & \\
\hline & Housing (108) & \\
\hline
\end{tabular}

